\title{
Bathymetric control of tidewater glacier mass loss in northwest Greenland
}

\author{
David F. Porter ${ }^{\mathrm{a}, *}$, Kirsty Tinto ${ }^{\mathrm{a}}$, Alexandra Boghosian ${ }^{\mathrm{a}}$, James R. Cochran ${ }^{\mathrm{a}}$, Robin E. Bell ${ }^{\mathrm{a}}$, \\ Serdar S. Manizade ${ }^{b}$, John G. Sonntag ${ }^{b}$ \\ a LDEO, Columbia University, 61 Route 9W, Palisades, NY, USA \\ ${ }^{\mathrm{b}}$ URS Corporation, Wallops Flight Facility, USA
}

\section{A R T I C L E I N F O}

\section{Article history:}

Received 2 January 2014

Received in revised form 22 April 2014

Accepted 29 May 2014

Available online $\mathrm{xxxx}$

Editor: J. Lynch-Stieglitz

\section{Keywords:}

Greenland

marine-terminating glaciers

fjord bathymetry

ice-ocean interactions

\begin{abstract}
A B S T R A C T
It has been suggested that fjord geometry could be an important contributor to the observed mass loss variability in Greenland by modulating the flow of warm water to marine-terminating glaciers. New gravity-derived bathymetry of Greenlandic fjords confirms the link between the grounding line depth and rates of glacier mass loss, a relationship previously predicted only in ice models. We focus on two neighboring glaciers to minimize differences in external forcing and therefore isolate the role of the fjord bathymetry. Tracy Glacier has a deeper grounding line and has been retreating since 1892 with a contemporary mass budget of $-1.63 \mathrm{Gta}^{-1}$. Heilprin Glacier has a shallower grounding line depth, a stable ice terminus, and a mass budget of only $-0.53 \mathrm{Gt} \mathrm{a}^{-1}$. Because of its deeper grounding line, Tracy has more ice in contact with warm subsurface water, leaving it more vulnerable to changes in ocean forcing and therefore mass loss.
\end{abstract}

(C) 2014 Published by Elsevier B.V.

\section{Introduction}

The mass budget of the Greenland ice sheet has decreased from $-51 \pm 65 \mathrm{Gta}^{-1}$ over the period $1992-2000$ to $-211 \pm$ $37 \mathrm{Gta}^{-1}$ over the period 2002-2011, contributing to a $7.9 \pm$ $2.7 \mathrm{~mm}$ rise in global mean sea level since 1992 (Rignot et al., 2012; Shepherd et al., 2012). Most of the ice sheet's mass loss is occurring at its margins, but the pattern of change is complex. There is considerable spatial and temporal variability in the observed ice surface velocity (Moon et al., 2012; Padman et al., 2012; Rignot and Jacobs, 2002) and mass wastage (Jakobsson et al., 2012; Kjeldsen et al., 2013; Pritchard et al., 2009; Shepherd et al., 2012) of outlet glaciers, complicating regional interpretations of change. Although tidewater glaciers in northwest Greenland showed an overall acceleration from 2000-2010, the changes in ice speed were not uniform (Melling et al,, 2001; Moon et al., 2012). In several instances, while one glacier sped up dramatically, its neighbors accelerated less or even slowed. This large degree of spatial variability precludes the scaling up of local thinning rates to ice sheet-wide mass wastage estimates (Gardner et al., 2013; Rignot et al., 2012), while the interannual variability hampers extrapolation of these trends into the future. Understanding this

\footnotetext{
* Corresponding author.

E-mail address: dporter@ldeo.columbia.edu (D.F. Porter).
}

observed variability is the next step in identifying the first-order components of the tidewater glacier system.

The external forcings of a tidewater glacier system that contribute to decadal scale glacier advance and retreat are surface energy and mass balance (SMB) (Box et al., 2012; O'Leary and Christoffersen, 2013), ocean heat content (Xu et al., 2012), and the subglacial environment (e.g. geothermal heat flux and subglacial and englacial hydrology) (Phillips et al., 2013). Adequate constraints of these forcings remain elusive due to both the inaccessibility and spatial variability of the glacial environments. This presents a significant challenge to understanding the observed variability in glacier retreat in Alaska, Greenland, and Antarctica.

Ice flow models have suggested that tidewater glaciers are most sensitive to forcing at the terminus (Nick et al., 2009), with the thinning and speed up response propagating inland (Howat et al., 2007). Furthermore, marine-terminating glaciers are most sensitive to melting at the base of the grounded ice at the grounding line (O'Leary and Christoffersen, 2013; Reeh, 1968). The grounding line is typically the site of the largest thermal forcing, the difference between the temperature of warm, deep water and the freezing point of salt water (Jacobs et al., 2012). The bed topography beneath the grounded outlet glacier may control the extent of the retreat (Enderlin et al., 2013; Schoof, 2007) while the fjord bathymetry controls the access of relatively warm water to the ice front at the grounding line (Holland et al., 2008). 


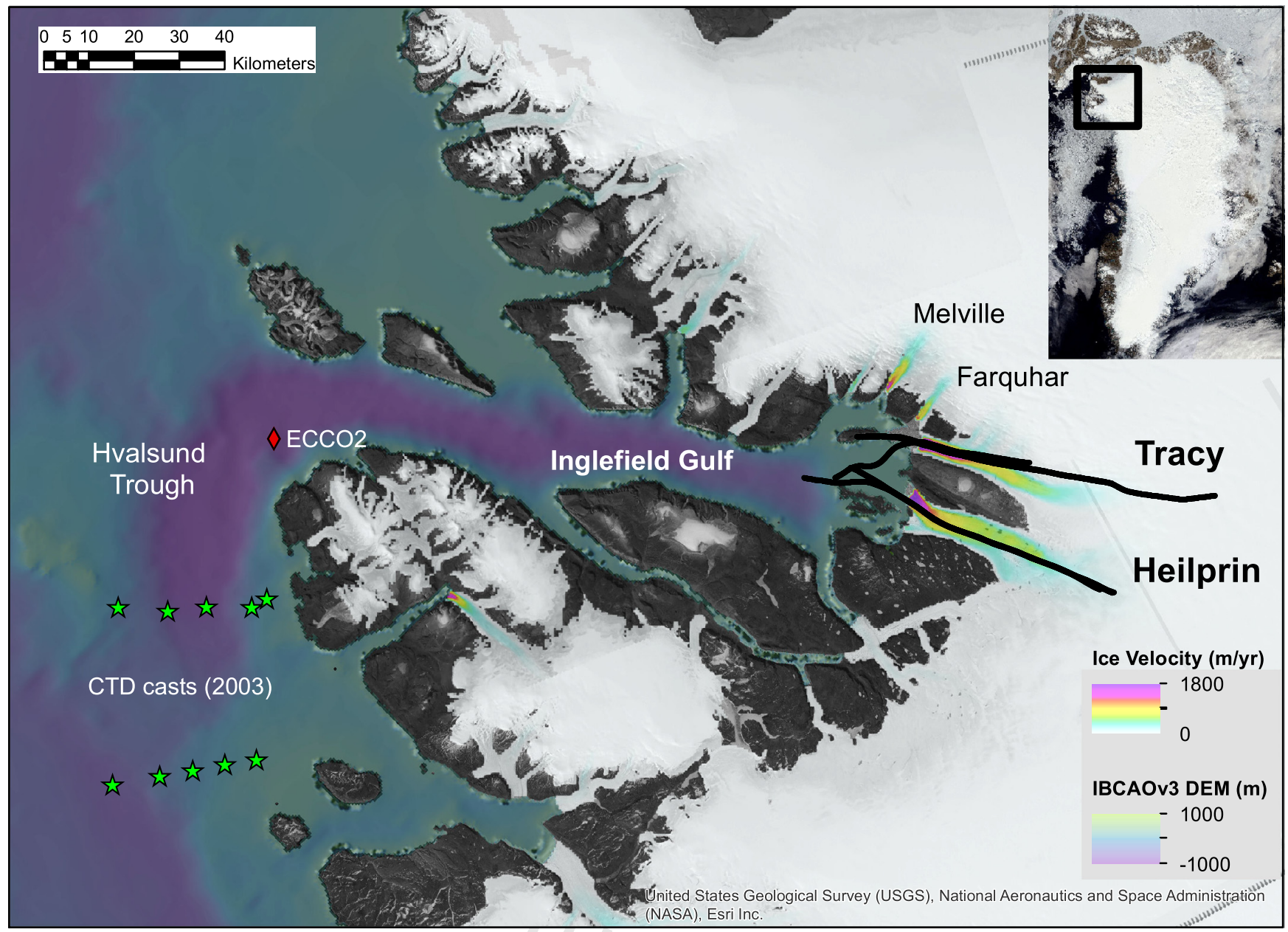

Fig. 1. Inglefield Gulf and surrounding glaciers, located in northwest Greenland. Landsat 7 panchromatic image over land and ice with IBCAO offshore. Locations of CTD and ECCO2 model data. Also shown are NASA MEaSUREs ice velocities.

Here, we analyze a pair of neighboring glaciers to minimize the differences in external forcings between the two systems. This case study approach assumes the glaciers terminating in the same fjord will experience similar changes in ocean properties. We also assume the subglacial thermal and hydrological environment is similar between neighboring glaciers. Finally, while SMB can vary widely across Greenland (Vernon et al., 2012), proximal glaciers will have similar SMB forcings. We analyze Tracy and Heilprin Glaciers, two similarly sized neighboring glaciers in northwest Greenland that both empty into Inglefield Gulf (Fig. 1).

\section{Tracy and Heilprin Glaciers}

Tracy and Heilprin Glaciers are the widest $(\sim 5 \mathrm{~km})$ of the marine-terminating glaciers that flow into Inglefield Gulf in NW Greenland $\left(77^{\circ} \mathrm{N}\right)$ (Fig. 1). A 115 -year record of terminus positions of Tracy and Heilprin Glaciers, compiled from reports of early Arctic explorers, geologists, and more recently aerial and satellite images, reveal disparate long term mass-wasting of these two neighboring glaciers (Dawes and van As, 2010). At the start of the 20th century, the terminus of Tracy Glacier extended to the island, Josephine Peary Øer, with both Melville and Farquhar Glaciers flowing into it as tributaries from the north (Fig. 2). Tracy Glacier detached from Peary Øer in 1960 (Dawes and van As, 2010) but did not recede significantly through 2000 . The period of fast terminus retreat was from 2000-2005 when Tracy pulled back another $8 \mathrm{~km}$, finally detaching from its last tributary, Farquhar Glacier. Landsat images show a transition from tabular to fluted icebergs around 2005 , indicating a change from a floating to grounded terminus (Walter et al., 2010), corroborated by the attendant appearance of glacier-quakes from Tracy (Veitch and Nettles, 2012). Over the next eight years (from 2005 to 2013), Tracy's terminus retreated another $2 \mathrm{~km}$ further inland. It is probable that Tracy's terminus was floating for most of the past century. Using a combination of survey maps, aerial photography, and satellite imagery, Dawes and van As (2010) show that Tracy has retreated by about $15 \mathrm{~km}$ since Peary's first expedition there in 1892. By comparison, the terminus position of Heilprin Glacier has changed less than $4 \mathrm{~km}$ in that time.

During the same period, the other four significant glaciers terminating in the waters at the eastern end of Inglefield Gulf have also retreated, but by much less. These four small glaciers are from west to east: Hart, Sharp, Melville, and Farquhar. The largest retreats for these glaciers, approximately $1.5 \mathrm{~km}$, occurred for Melville, and Farquhar that only recently separated from the main trunk of Tracy. Tracy had previously provided additional backstress to the outflowing ice from these two glaciers.

Warming ocean waters around both Greenland (Rignot et al., 2012) and Antarctica (Padman et al., 2012; Rignot and Jacobs, 2002) have been implicated as a trigger of the recent mass loss from these ice sheets. In the cold waters of high latitudes, the pycnocline is mainly a reflection of gradients in salinity, resulting in a fresh and cold surface with warm saline water below. The heat contained in the underlying warm Atlantic Water 

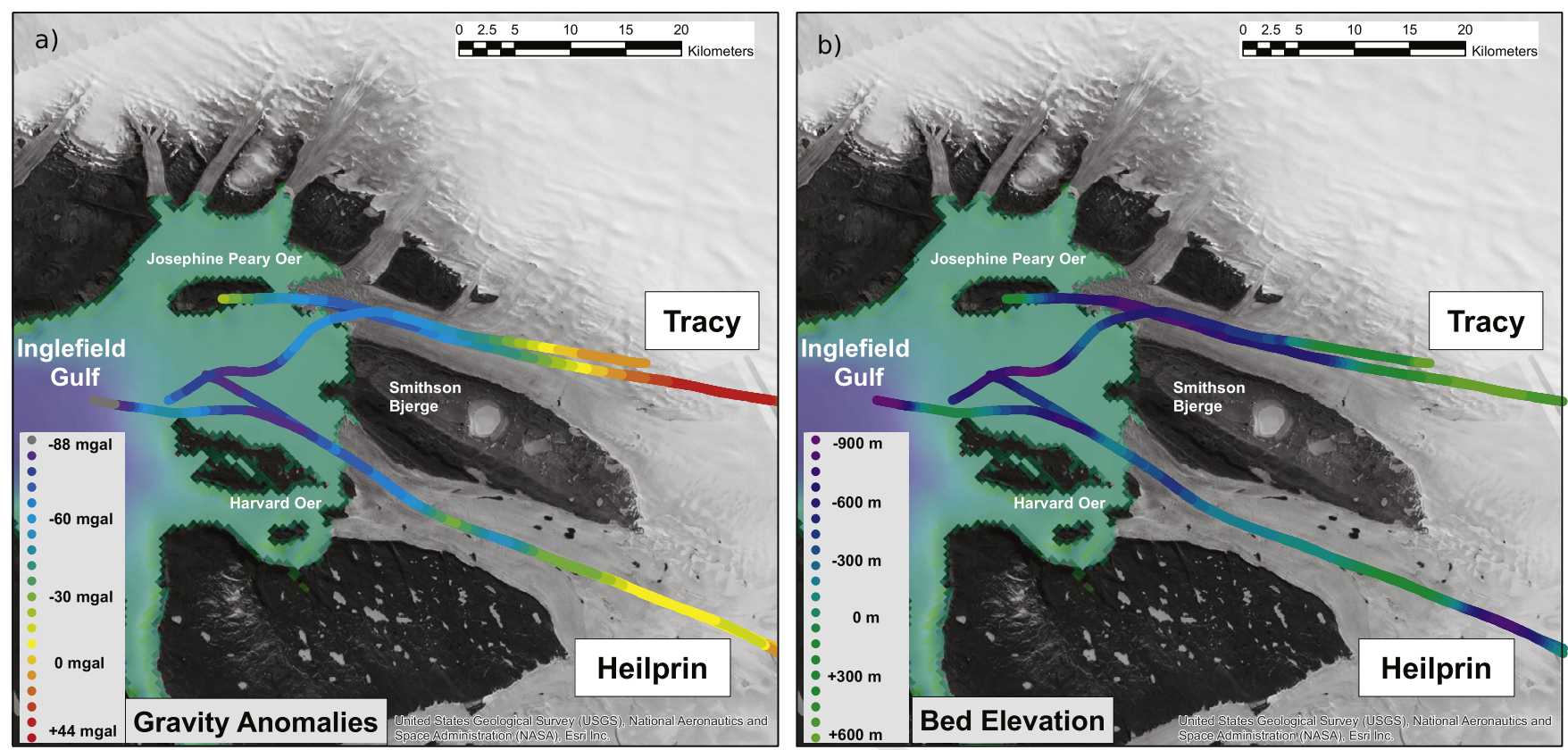

Fig. 2. Landsat 7 panchromatic image and IBCAO water depths of Inglefield Gulf and surrounding glaciers. The colors of NASA OIB flight lines depict the (a) measured free-air gravity anomalies and (b) modeled depth of the bed in meters above sea level. (For interpretation of the references to color in this figure legend, the reader is referred to the web version of this article.)

(AW), typically found below $100 \mathrm{~m}$, is available to melt marineterminating glaciers.

Tracy and Heilprin Glaciers are located at the head of Inglefield Gulf in northwest Greenland (Fig. 2). The International Bathymetric Chart of the Arctic Ocean (IBCAO) Version 3.0 (Jakobsson et al, 2012) indicates this gulf is a long and straight channel that is approximately $80 \mathrm{~km}$ long and $10 \mathrm{~km}$ wide with no known sills. Inglefield Gulf extends seaward to Hvalsund, a $1 \mathrm{~km}$ deep trough that turns southward towards the Carey Islands and out into northern Baffin Bay (Fig. 1). The deep north-south Hvalsund trough at the mouth of Inglefield Gulf may provide a pathway for the northward transport of warm and deep Atlantic Water in the West Greenland Current (WGC). Oceanographic moorings from northern Baffin Bay to the Smith Sound (Melling et al., 2001) suggest that the deep waters of the WGC bifurcate at a sill in northern Baffin Bay, with one branch flowing north into Hvalsund trough. This branch of relatively warm water is likely the source of the water in Inglefield Gulf (Dybkjaer et al., 2011), which ultimately reaches the ice faces of Tracy and Heilprin Glaciers.

Summertime water temperatures in Hvalsund trough were obtained from a series of hydrographic casts in 2003 (https://www. aoncadis.org/dataset/Healy2003-01-CTD.html) (Münchow et al., in press). The cast locations are shown in Fig. 1. Fig. 3 shows a comparison of these observations with nearby temperature profiles from the Estimating the Circulation and Climate of the Ocean model II (ECCO2, from http://ecco2.org) (Rignot et al., 2012). In general, there is warm fresh surface water $\left(>2^{\circ} \mathrm{C}\right)$ down to $50 \mathrm{~m}$ and warm AW water $\left(>0^{\circ} \mathrm{C}\right)$ below $150 \mathrm{~m}$ depth. The thermal minimum, with temperatures of $-0.5^{\circ} \mathrm{C}$ to $-1.6^{\circ} \mathrm{C}$, occurs between $50-100 \mathrm{~m}$ depth. The ECCO2 model properly simulates the strong halocline but has less detail than the casts and underestimates the AW temperature (Fig. 3). Glaciers are most sensitive to melting at the base of the ice face (O'Leary and Christoffersen, 2013), driven by the difference between this warm AW layer and the freezing point of sea water at the grounding line $\left(\sim-2{ }^{\circ} \mathrm{C}\right.$, from Fig. 3). In addition to this thermal forcing, frontal ablation works in tandem with the force-convective subglacial meltwater plume to drive melting of the face (Xu et al., 2012). The conse-

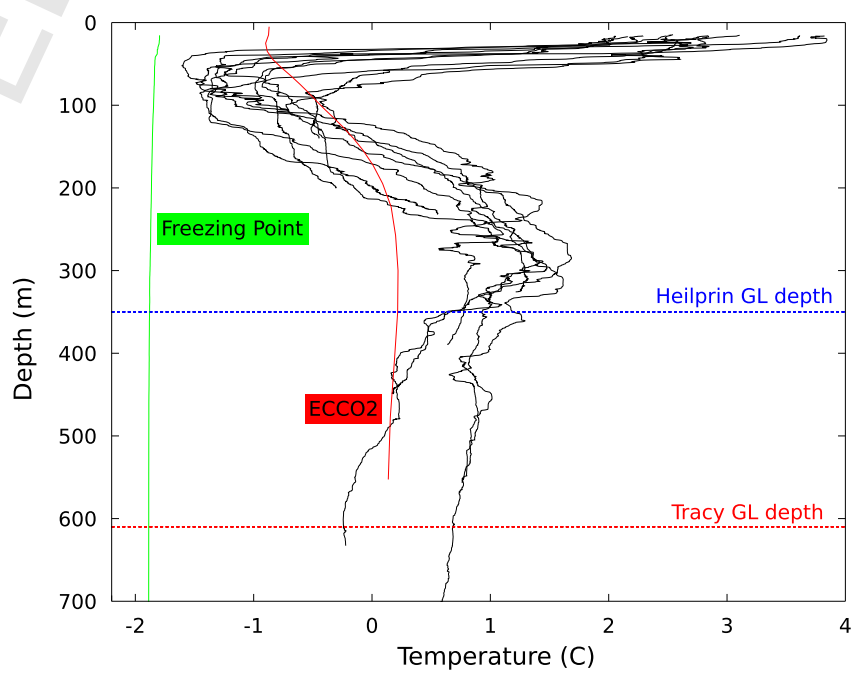

Fig. 3. Profile plots of temperature versus depth for the ECCO2 model (red) and all CTD casts in Hvalsund trough (black). Also included is the freezing point of seawater (green) for the deepest cast. For reference, the grounding line depths of both Tracy (red) and Heilprin (blue) Glaciers are included as dotted lines. See Fig. 1 for locations hydrographic data. (For interpretation of the references to color in this figure legend, the reader is referred to the web version of this article.)

quence of this large difference is that ice at or below $100-150 \mathrm{~m}$ depth will incur more frontal ablation than shallower ice.

\section{Mass balance and response of Tracy and Heilprin Glaciers to forcing}

\subsection{Mass wastage and surface lowering}

We use NASA Airborne Topographic Mapper (ATM) lidar (Krabill et al., 2002) to detect surface elevation change rates using airborne altimetry. We derive thinning rate estimates from coincident ice surface elevation measurements (Martin et al., 2012). We focus 
a) Tracy Glacier $d h / d t$

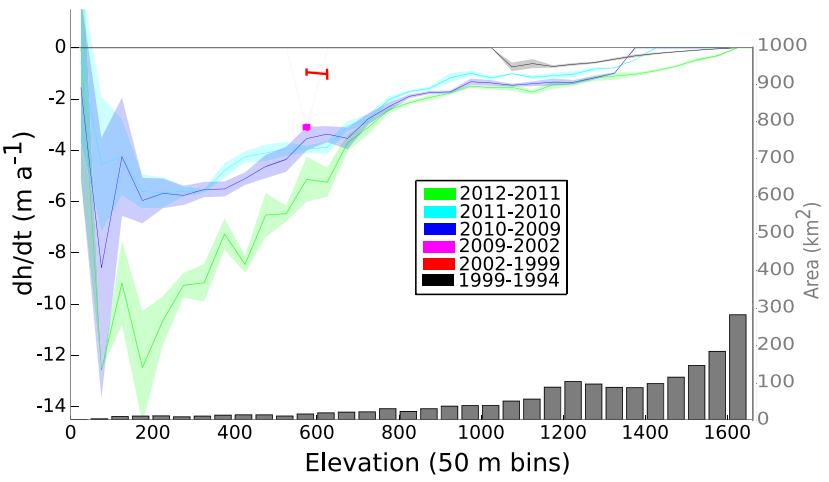

b) Heilprin Glacier dh/dt

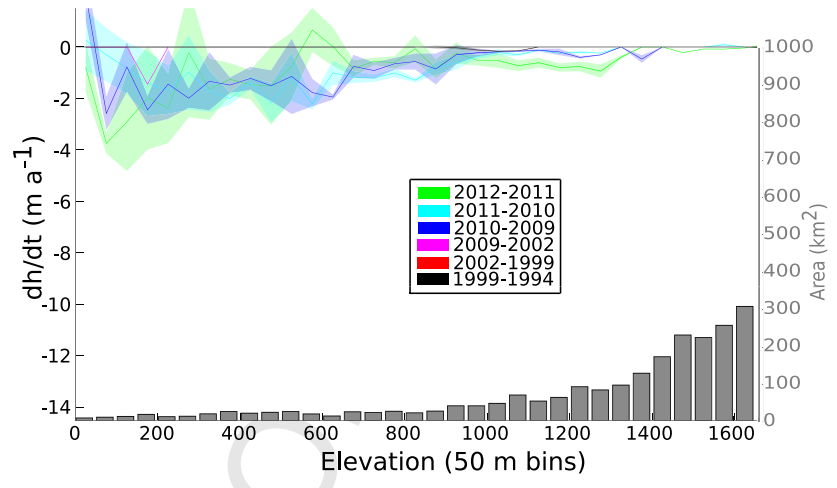

67

68

69

70

71

72

73 spective elevation bins as derived from the Greenland Ice Mapping Project (GIMP) DEM (http://bprc.osu.edu/GDG/gimpdem.php). For Alaskan glaciers, Berthier et al. (2010) find that extrapolating center-line altimetry measurements across elevation bins overestimates the area-average thinning rates by $22 \%$. This should be inconsequential for this study because Tracy and Heilprin have similar width-scales. The glacier-mean thinning rate of Tracy is $-0.5 \mathrm{ma}^{-1}$, which is equivalent to a mass budget of $-1.63 \pm$ $0.26 \mathrm{Gta}^{-1}$. By contrast, the same calculation for Heilprin yields a thinning rate of $-0.07 \mathrm{ma}^{-1}$ and a mass budget of $-0.53 \pm$ $0.6 \mathrm{Gta}^{-1}$.

\subsection{Ice velocity}

The MEaSUREs program provides ice sheet-wide mosaics of annual mean ice surface velocity for the period from March 2001 through March 2008 from RADARSAT-1 (Joughlin et al., 2010). Starting in 2010, higher resolution velocity tiles are available for locations around Greenland's largest outlet glaciers from TerraSAR$\mathrm{X}$ data. We sample these velocities under every OIB flight line between 2009 and 2012 to ensure spatial colocation with $\mathrm{d} h / \mathrm{d} t$ determinations and also to sample the fastest ice flow. As with the thinning rate calculations, the data are filtered and processed into elevation bins of $20 \mathrm{~m}$.

Fig. 5 shows that the ice surface velocity near the terminus from 2000-2011 is about $1.6 \mathrm{~km} \mathrm{a}^{-1}$ for Tracy and $1.3 \mathrm{~km} \mathrm{a}^{-1}$ for Heilprin. There was a large acceleration in both glaciers between 2001 and 2006, when Tracy accelerated by about 40\% or over $300 \mathrm{~m} \mathrm{a}^{-1}$, but Heilprin sped up by only $150-200 \mathrm{ma}^{-1}$ (Rignot and Kanagaratnam, 2006). Moon et al. (2012) find similar velocity changes in these two glaciers (a 20\% increase for Tracy and 15\% for Heilprin) between 2000 and 2010 using satellite interferometry and speckle tracking. The timing of this change suggests that both glaciers are responding to identical external forcing, such as a pulse of warm water in the WGC associated to a reduction in the North Atlantic Oscillation (NAO) (Rignot et al., 2012), although Tracy responds more. Since 2006, both glaciers have experienced more modest increases in speed, with 2011 as the fastest year for both glaciers (above $150 \mathrm{~m}$ elevation). The speedup propagated inland for both in recent years, although the acceleration was more pronounced in Tracy. We calculate the 2009-2012 mass flux of Tracy and Heilprin to be $2.3 \pm 0.1 \mathrm{Gta}^{-1}$ and $1.8 \pm 0.1 \mathrm{Gta}^{-1}$, respectively. The uncertainty in mass flux estimates comes from the summation of uncorrelated errors associated with InSAR surface velocities, radar bed depths, and by the assumptions that ice surface velocities scale to a depth-averaged velocity and of a parabolic
74

75

76

77

78

79

80

81

82

83

84

85

86

87

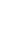
. 7

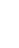
a . 
a) Tracy ice velocity

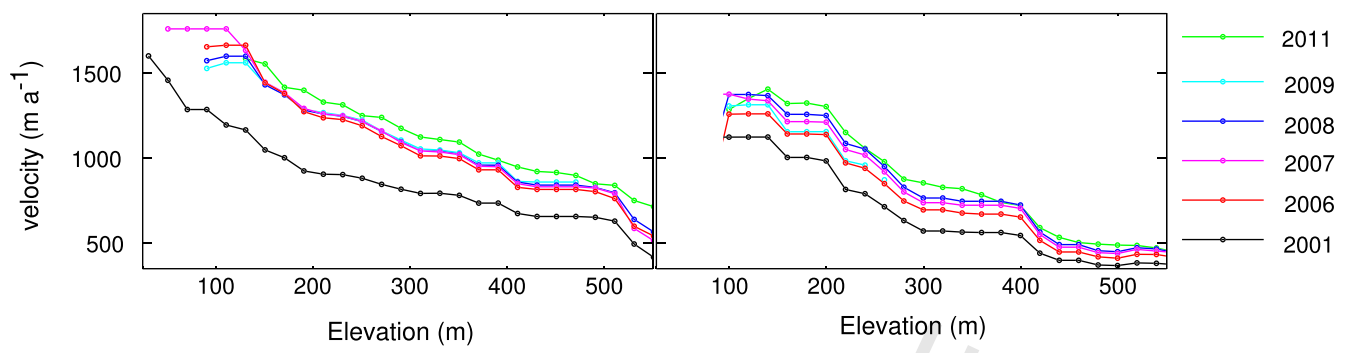

Fig. 5. Ice surface velocity from InSAR technique in meters per year for each winter-to-winter period (calculated as departures from the $2001-2011 \mathrm{mean}$ ) for each $20 \mathrm{~m}$ elevation bin for Tracy (left) and Heilprin (right). Each labeled year in the figure is representative of the preceding winter (e.g. March 2000-March 2001 is labeled as "2001"). Velocities are sampled at the locations of $\mathrm{d} h / \mathrm{d} t$ determinations.

\section{a) Tracy}

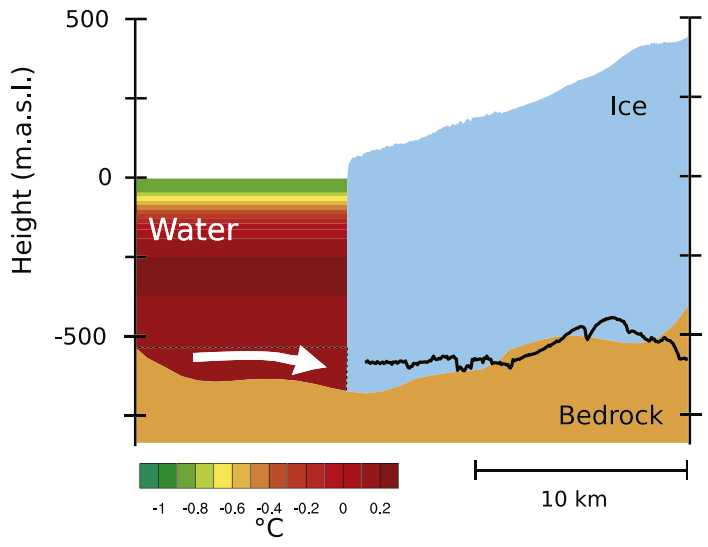

b) Heilprin

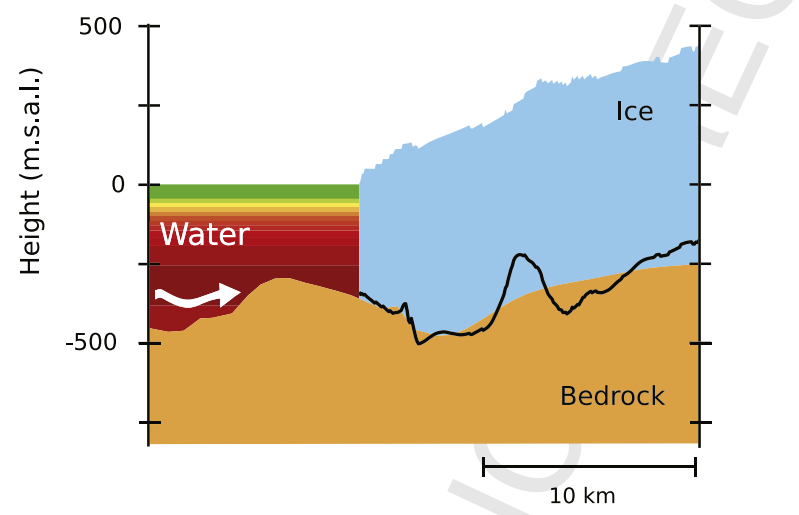

Fig. 6. Gravity-derived topographic profiles for (a) Tracy and (b) Heilprin Glaciers. The models are displayed with their grounding lines aligned. The overlaid black lines are observed bed elevations from OIB radar. Water potential temperatures in Celsius are from ECCO2 model output at mouth of Inglefield Gulf, over $100 \mathrm{~km}$ from the ice face. Water temperature below $550 \mathrm{~m}$ depth (dotted line) are arbitrarily colored the same as the next shallowest water layer. (For interpretation of the references to color in this figure legend, the reader is referred to the web version of this article.)

glacier cross-sectional profile (constrained by ice thicknesses from NASA OIB radar).

\section{Bathymetry from inversion of IceBridge gravity data}

We used Operation IceBridge gravity data to invert for bathymetry beneath Inglefield Gulf at the terminus of the two glaciers. OIB gravity data were obtained with a Sander Geophysics AIRGrav airborne gravimeter (Argyle et al., 2000; Sander et al., 2004). The AIRGrav system provides high-quality data during draped flights, flown at a constant elevation above the ice surface (Studinger et al., 2008), such as the OIB centerline flights along Tracy and Heilprin Glaciers, flown at a nominal height of 1500 feet $(457 \mathrm{~m})$ above the surface. The gravity anomalies were filtered with a $70 \mathrm{~s}$ full wavelength filter, resulting in a $\sim 4.2 \mathrm{~km}$ half-wavelength resolution for a typical flying speed of $120 \mathrm{~m} / \mathrm{s}$ (Fig. 2a). The bed rise seen in the radar $\sim 5 \mathrm{~km}$ inland from Heilprin's grounding line (Fig. 6b), likely the inland extension of Harvard Øer (Fig. 2b), illustrates the resolution of the gravimeter. The resulting bathymetry inversions will depress and diffuse any feature either shorter than the intrinsic resolution of the gravimeter or that does not fully extend across the fjord. This limitation is adequate for a study on the first-order effect of fjord geometry on glacier melt because the small unresolved features will not have first-order impacts on a glacier's access to warm AW.

One of the derived products of the airborne gravimetry program is inversion of the gravity data to obtain bathymetry (Tinto and Bell, 2011a) in waters inaccessible to traditional ship-based ocean bottom surveys. These gravity inversions can also fill-in gaps in the ice-base depth derived from radar on the steep and heavily crevassed lower portions of glaciers, where radar power dissipates before the sharp ice/rock interface. Repeat-track OIB flight lines were flown over grounded ice to construct continuous time series of change in the cryosphere. Over open water or floating ice, such as in Inglefield Gulf, flights do not always occupy previous tracks, resulting in wider spatial gravity coverage (Fig. 2b).

Inversion of the gravity data for bathymetry was undertaken in two-dimensions along individual flight lines using Geosoft GMSys software. The software does iterative forward modeling using the technique of Talwani et al. (1959). We assume a constant rock density of $2.67 \mathrm{~g} \mathrm{~cm}^{-3}$ and the absence of sediments. In the model, the bed is kept fixed where it is observed in the radar data, while the bathymetry in water-covered areas (where the seafloor cannot be imaged with radar) is varied to obtain the best match to the observed gravity (Tinto and Bell, 2011b). The uncertainty in the bathymetry estimates, determined from comparison against known bathymetry and other flight lines, range from \pm 50 to $\pm 150 \mathrm{~m}$ depending on the proximity to constraints.

The most significant difference between these two glaciers is that the water depth near and seaward of the grounding line of Tracy is $250-350 \mathrm{~m}$ deeper than Heilprin (Fig. 6). The models for Tracy show a mostly flat bed at a depth of $\sim 600$ meters below sea level within $10 \mathrm{~km}$ of either side of the present day grounding line. For Heilprin, the bathymetry is also mostly flat at about $350 \mathrm{~m}$ depth, with a $220 \mathrm{~m}$ depth sill only $4 \mathrm{~km}$ seaward of the grounding line. Although an inland-sloping bed has been implicated as an intrinsic driver of irreversible grounding line retreat (Meier and Post, 1987), Heilprin is changing more slowly than Tracy, whose bed is not sloping. Most importantly, at the grounding line, Tracy 
AW than Heilprin, con-

has 250-350 m more ice exposed to warm AW than Heilprin, contributing to the increased sensitivity of Tracy to ocean warming (Fig. 6).

The asymmetry of the fjord just seaward of the grounding line is illustrated in Fig. 2b, which shows the new gravity-derived bathymetry for Tracy and Heilprin. The continuity of the underwater feature between Peary Øer and Smithson Bjerge is clearly shown, but sinuous flight-geometry seaward of the terminus gives increased cross-over errors of $\pm 130 \mathrm{~m}$ for the bathymetry model. The deepest part of the fjord lies between Peary and Harvard Øers at $-830 \mathrm{~m}$ depth with a sill between Peary Øer and Smithson Bjerge of only $-300 \mathrm{~m}$ depth (Fig. 2b). This lateral sill between Tracy and Heilprin suggests a distinctly different pathway of the water reaching each ice face.

\section{A mass balance approach for estimating ocean forcing}

Following Hulbe et al. (2013), we write out the mass balance equation as follows:

$\dot{M}=\dot{b}-(\overline{u h}+\dot{q})$

where $\dot{M}$ is the mass balance from integrating ATM thinning rates (discussed in Section 3.1), $\dot{b}$ is surface accumulation from the Regional Arctic Climate MOdel version II for GReenland (RACMO2/GR) (van Angelen et al., 2012) integrated over the surface catchment area, $\overline{u h}$ is mass flux (described in Section 3.2), and $\dot{q}$ is ocean forcing. As discussed above in Section 3, the mass flux term $\overline{u h}$ is calculated with the assumptions of a parabolic ice cross-section (Graf, 1970) and that the depth-averaged ice velocity is 0.8 times the surface velocity (Cuffey and Paterson, 2010). All terms are calculated as annual values over the period 2009-2012. The "ocean forcing" term $\dot{q}$ is calculated as a residual (Rignot et al., 2013) and encompasses both the melt of the ice face as well as calving. For glaciers that are well-constrained by observations, this mass balance approach is useful for comparing the relative importance of the ocean forcing to other external forcings (e.g., changes in surface mass balance due to atmospheric warming). Ocean forcing for this period is $0.86 \pm 0.27 \mathrm{Gta}^{-1}$ for Tracy and $0.64 \pm 0.62 \mathrm{Gta}^{-1}$ for Heilprin. Although uncertainties in the calculated term are large (a result of large uncertainties in mass loss term), these estimates help quantify differences in ocean forcing resulting from different grounding line depths between Tracy and Heilprin.

The connection between a deep grounding line and increased mass wastage, at least for Tracy and Heilprin Glaciers and perhaps others in northwest Greenland, assumes there is warmer water at depth which leads to increased melt of the ice face. At the grounding line, Tracy has 250-350 m greater vertical extent of ice exposed to warm AW than Heilprin. This increased melt, concentrated at the deepest part of the ice, may either drive retreat directly by melt or indirectly by undercutting the ice and increasing the calving rate. For either mechanism, the proposed link from increased basal melt to thinning is as follows; increased melt thins ice at the grounding line and leads to tongue disintegration or undercutting of the vertical ice face, reducing backstresses on the grounded ice, and resulting in faster ice flow and a deflation of the inland ice which must supply more ice to the grounding line.

Other aspects of fjord geometry, such as bed shape, sills, and ice rises, contribute to observed variability in tidewater glacier retreat. The known bathymetry in Inglefield Gulf (Fig. 1) does not show the presence of sills. However, any sills within the Gulf would restrict the flow of warm AW to each glacier equally. Harvard Øer may be acting as an ice rise, stabilizing Heilprin, which still has a short floating tongue. Modeling indicates that ice grounded on an inland sloping bed will be less stable and change more rapidly (Schoof, 2007; Vieli et al., 2002). Heilprin has an inland-sloping bed at and seaward of grounding line but is changing more slowly. For this pair of glaciers, the depth of the fjord at the grounding line is the most important control on how the ocean interacts with these marine-terminating glaciers.

\section{Conclusions}

Defining and quantifying the impact of fjord bathymetry (including the depth of the grounding line, the presence of sills, and troughs across the shelf) on glacier mass loss is crucial for modeling the interactions between warm Atlantic Water and deepgrounded ice, ultimately improving estimates of mass wastage and sea level rise. We show that airborne gravity inversions of fjord bathymetry, although inherently limited in resolution due to the height and groundspeed of the airplane, have proven to reliably capture the bed features that would significantly affect the circulation and the delivery of oceanic heat to the ice face.

Using new gravity-derived bathymetry and mass-balancederived ocean forcing, we analyze a pair of neighboring glaciers in northwest Greenland with similar external forcings and find that grounding line depth explains much of the variability in their recent mass loss. We believe that this is a fundamental first-order relationship that extends to other tidewater glaciers around Greenland. If such a relationship exists, we can conclude that deeper tidewater glaciers in Greenland are more sensitive to warming ocean temperatures than those that terminate in shallow water. We also note that other aspects of fjord geometry, such as its width and the presence of sills shallower than the depth of Atlantic Water, can modulate and even supersede the influence of a deeply grounded terminus.

For glaciers that are well-constrained by observations, the mass balance equation can be exploited to estimate ocean forcing, a term combining the effects of basal melt and calving. This analysis can be done for glaciers observed by NASA Operation IceBridge campaigns, although an increase in the spatial coverage of thinning rate data will be required to calculate ocean forcing this way for most of the glaciers in Greenland. The findings of this study suggest that measuring the fjord geometry of Greenland's outlet glaciers may aid in the prediction of which glaciers are most sensitive to warming ocean waters, thereby improving ice/ocean interaction models, as well as forecasts of future mass wastage and resulting sea level rise.

\section{Acknowledgements}

The authors would like to thank very helpful assistance from Indrani Das, Tim Creyts, Andreas Münchow, and Ben Smith, for their assistance in developing this paper. Jan van Angelen provided the RACMO2/GR surface accumulation data. This project was funded through NASA grants NNX12AB70G, NNX10AT69G, and NNX13AD25A.

\section{References}

Argyle, M., Ferguson, S., Sander, L., Sander, S., 2000. AIRGrav results: a comparison of airborne gravity data with GSC test site data. Lead. Edge 19 (10), 1134-1138. http://dx.doi.org/10.1190/1.1438494.

Berthier, E., Schiefer, E., Clarke, G.K.C., Menounos, B., Rémy, F., 2010. Contribution of Alaskan glaciers to sea-level rise derived from satellite imagery. Nat. Geosci. 3 (2), 92-95. http://dx.doi.org/10.1038/ngeo737.

Box, J.E., Fettweis, X., Stroeve, J.C., Tedesco, M., Hall, D.K., Steffen, K., 2012. Greenland ice sheet albedo feedback: thermodynamics and atmospheric drivers. Cryosphere 6 (4), 821-839. http://dx.doi.org/10.5194/tc-6-821-2012.

Cuffey, K.M., Paterson, W., 2010. The Physics of Glaciers, fourth edition. Elsevier.

Dawes, P.R., van As, D., 2010. An advancing glacier in a recessive ice regime: Berlingske Brae, North-West Greenland. In: Geological Survey of Denmark and Greenland Bulletin, vol. 20, pp. 79-82.

Dybkjaer, G., Høyer, J., Tonboe, R., Olsen, S., Rodwell, S., Wimmer, W., Sobjaerg, S., 2011. QASITEEX - 2011: The Qaanaaq Sea Ice Thermal Emission EXperiment Field and data report. Danish Meteorological Institute, Copenhagen, Denmark. Obtained from www.dmi.dk/dmi/tr11-18.pdf. 
Enderlin, E.M., Howat, I.M., Vieli, A., 2013. High sensitivity of tidewater outlet glacier dynamics to shape. Cryosphere 7 (3), 1007-1015. http://dx.doi.org/10.5194/ tc-7-1007-2013.

Gardner, A.S., et al., 2013. A reconciled estimate of glacier contributions to sea level rise: 2003 to 2009. Science 340 (6134), 852-857. http://dx.doi.org/10.1126/ science.1234532.

Graf, W.L., 1970. The geomorphology of the glacial valley cross section. Arctic Alpine Res., 303-312. http://dx.doi.org/10.1016/S0169-555X(00)00078-7.

Holland, D.M., Thomas, R.H., De Young, B., Ribergaard, M.H., Lyberth, B., 2008. Acceleration of Jakobshavn Isbrae triggered by warm subsurface ocean waters. Nat. Geosci. 1 (10), 659-664. http://dx.doi.org/10.1038/ngeo316.

Howat, I.M., Joughin, I., Scambos, T.A., 2007. Rapid changes in ice discharge from Greenland outlet glaciers. Science 315 (5818), 1559-1561. http://dx.doi.org/ $10.1126 /$ science.1138478.

Hulbe, C.L., Scambos, T.A., Lee, C.-K., Bohlander, J., Haran, T., 2013. Recent changes in the flow of the Ross Ice Shelf, West Antarctica. Earth Planet. Sci. Lett. 376, 54-62. http://dx.doi.org/10.1016/j.epsl.2013.06.013.

Jacobs, S., Jenkins, A., Hellmer, H., Giulivi, C., Nitsche, F., Huber, B., Guerrero, R., 2012. The Amundsen Sea and the Antarctic ice sheet. Oceanography 25 (3), 154-163.

Jakobsson, M., et al., 2012. The international bathymetric chart of the Arctic ocean (IBCAO) Version 3.0. Geophys. Res. Lett. 39. http://dx.doi.org/10.1029/ 2012GL052219.

Joughin, I., Smith, B., Howat, I., Scambos, T., 2010. MEaSUREs Greenland ice velocity map from InSAR data. In: NASA DAAC at the National Snow and Ice Data Center. Boulder, Colorado, USA. http://dx.doi.org/10.5067/measures/cryosphere/ nsidc-0478. (http://nsidc.org/data/nsidc-0478.html).

Kjeldsen, K.K., Khan, S.A., Wahr, J., Korsgaard, N.J., Kjær, K.H., Bjørk, A.A., Hurkmans, R., Broeke, M.R., Bamber, J.L., Angelen, J.H., 2013. Improved ice loss estimate of the northwestern Greenland ice sheet. J. Geophys. Res., Solid Earth.

Krabill, W.B., Abdalati, W., Frederick, E.B., Manizade, S.S., Martin, C.F., Sonntag, J.G., Swift, R.N., Thomas, R.H., Yungel, J.G., 2002. Aircraft laser altimetry measurement of elevation changes of the Greenland ice sheet: technique and accuracy assessment. J. Geodyn. 34 (3-4), 357-376.

Martin, C.F., Krabill, W.B., Manizade, S.S., Russell, R.L., Sonntag, J.G., Swift, R.N., Yungel, J.K., 2012. Airborne topographic mapper calibration procedures and accuracy assessment. NASA Technical Reports, Vol. 20120008479(NASA/TM-2012-215891, GSFC.TM.5893.2012). http://hdl.handle.net/2060/20120008479.

Meier, M.F., Post, A., 1987. Fast tidewater glaciers. J. Geophys. Res. 92 (B9), 9051. http://dx.doi.org/10.1029/JB092iB09p09051.

Melling, H., Gratton, Y., Ingram, G., 2001. Ocean circulation within the North Water polynya of Baffin Bay. Atmos.-Ocean 39 (3), 301-325. http://dx.doi.org/10.1080/ 07055900.2001.9649683.

Moholdt, G., Nuth, C., Hagen, J.O., Kohler, J., 2010. Recent elevation changes of Svalbard glaciers derived from ICESat laser altimetry. Remote Sens. Environ. 114 (11), 2756-2767. http://dx.doi.org/10.1016/j.rse.2010.06.008.

Moon, T., Joughin, I., Smith, B.E., Howat, I., 2012. 21st-century evolution of Greenland outlet glacier velocities. Science 336 (6081), 576-578. http://dx.doi.org/ $10.1126 /$ science.1219985.

99 Münchow, A., Falkner, K.K., Melling, H., in press. Baffin Island and West Greenland current systems in northern Baffin Bay. Prog. Oceanogr. 27 pp.

Nick, F.M., Vieli, A., Howat, I.M., Joughin, I., 2009. Large-scale changes in Greenland outlet glacier dynamics triggered at the terminus. Nat. Geosci. 2 (2), 110-114. http://dx.doi.org/10.1038/NGEO394.

O'Leary, M., Christoffersen, P., 2013. Calving on tidewater glaciers amplified by submarine frontal melting. Cryosphere 7 (1), 119-128. http://dx.doi.org/10.5194/ tc-7-119-2013.

Padman, L. et al., 2012. Oceanic controls on the mass balance of Wilkins Ice Shelf, Antarctica. J. Geophys. Res. 117 (C1), C01010. http://dx.doi.org/10.1029/ 2011JC007301.
Phillips, T., Rajaram, H., Colgan, W., Steffen, K., Abdalati, W., 2013. Evaluation of Q1067 cryo-hydrologic warming as an explanation for increased ice velocities in the 68 wet snow zone, Sermeq Avannarleq, West Greenland. J. Geophys. Res., Earth Surf.

Pritchard, H.D., Arthern, R.J., Vaughan, D.G., Edwards, L.A., 2009. Extensive dynamic thinning on the margins of the Greenland and Antarctic ice sheets. Nature 461 (7266), 971-975. http://dx.doi.org/10.1038/nature08471.

Reeh, N., 1968. On the calving of ice from floating glaciers and ice shelves. J. Glaciol. 7, 215-232.

Rignot, E., Jacobs, S.S., 2002. Rapid bottom melting widespread near Antarctic ice sheet grounding lines. Science 296 (5575), 2020-2023.

Rignot, E., Kanagaratnam, P., 2006. Changes in the velocity structure of the Greenland ice sheet. Science 311 (5763), 986-990. http://dx.doi.org/10.1126/science. 1121381.

Rignot, E., Fenty, I, Menemenlis, D., Xu, Y, 2012. Spreading of warm ocean waters around Greenland as a possible cause for glacier acceleration. Ann. Glaciol.

Rignot, E., Jacobs, S., Mouginot, J., Scheuchl, B., 2013. Ice-Shelf Melting Around Antarctica. Science 341 (6143), 266-270. http://dx.doi.org/10.1126/science. 1235798.

Sander, S., Argyle, M., Elieff, S., Ferguson, S., 2004. The AIRGrav airborne gravity system. In: Lane, R. (Ed.), Airborne Gravity 2004 - Abstracts from the ASEG-PESA Airborne Gravity 2004 Workshop.

Schoof, C., 2007. Ice sheet grounding line dynamics: steady states, stability, and hysteresis. J. Geophys. Res., Earth Surf. 112, F03S28. http://dx.doi.org/10.1029/ 2006JF000664.

Shepherd, A.P., et al., 2012. A reconciled estimate of ice-sheet mass balance. Science 338 (6111), 1183-1189. http://dx.doi.org/10.1126/science.1228102.

Studinger, M., Bell, R., Frearson, N., 2008. Comparison of AIRGrav and GT-1A airborne gravimeters for research applications. Geophysics 73 (6), I51-I61. http://dx.doi. org/10.1190/1.2969664.

Talwani, M., Worzel, J.L., Landisman, M., 1959. Rapid gravity computations for twodimensional bodies with application to the Mendocino submarine fracture zone. J. Geophys. Res. 64 (1), 49-59. http://dx.doi.org/10.1029/JZ064i001p00049.

Tinto, K.J., Bell, R.E., 2011a. IceBridge Sander AIRGrav L3 Bathymetry. NASA DAAC at the National Snow and Ice Data Center, Boulder, Colorado, USA.

Tinto, K.J., Bell, R.E., 2011b. Progressive unpinning of Thwaites Glacier from newly identified offshore ridge: constraints from aerogravity. Geophys. Res. Lett. 38. http://dx.doi.org/10.1029/2011GL049026.

van Angelen, J.H., Lenaerts, J.T.M., Lhermitte, S., Fettweis, X., Kuipers Munneke, P., van den Broeke, M.R., van Meijgaard, E., Smeets, C.J.P.P., 2012. Sensitivity of Greenland Ice Sheet surface mass balance to surface albedo parameterization: a study with a regional climate model. Cryosphere 6 (5), 1175-1186. http://dx.doi.org/10.5194/tc-6-1175-2012.

Veitch, S.A., Nettles, M., 2012. Spatial and temporal variations in Greenland glacialearthquake activity, 1993-2010. J. Geophys. Res., Earth Surf. 2003 (2012), 117(F4).

Vernon, C.L., Bamber, J.L., Box, J.E., van den Broeke, M.R., Fettweis, X., Hanna, E., Huy- Q13105 brechts, P., 2012. Surface mass balance model intercomparison for the Greenland ice sheet. Cryosphere 6, 3999-4036.

Vieli, A., Jania, J., Kolondra, L., 2002. The retreat of a tidewater glacier: observations and model calculations on Hansbreen, Spitsbergen. J. Glaciol. 48 (163), 592-600. http://dx.doi.org/10.3189/172756502781831089.

Walter, F., O'Neel, S., McNamara, D., Pfeffer, W.T., Bassis, J.N., Fricker, H.A., 2010. Iceberg calving during transition from grounded to floating ice, Columbia Glacier, Alaska. Geophys. Res. Lett. 37. http://dx.doi.org/10.1029/2010GL043201.

Xu, Y., Rignot, E., Menemenlis, D., Koppes, M., 2012. Numerical experiments on subaqueous melting of Greenland tidewater glaciers in response to ocean warming and enhanced subglacial discharge. Ann. Glaciol. 53 (60), 229. 